\title{
KAJIAN KAPASITAS, KEBUTUHAN, DAN EFEKTIVITAS PARKIR DI BANDAR UDARA EL TARI KUPANG
}

\author{
Amy Wadu ${ }^{1}$, Harnen Sulistio ${ }^{2}$, Achmad Wicaksono ${ }^{2}$ \\ ${ }^{1}$ Mahasiswa / Program Magister/ Jurusan Teknik Sipil/ Fakultas Teknik Universitas \\ Brawijaya \\ ${ }^{2}$ Dosen / Jurusan Teknik Sipil/ Fakultas Teknik Universitas Brawijaya \\ Jl. MT. Haryono No. 167 Malang, 65145, Jawa Timur \\ Email : awd.ub15@gmail.com
}

\begin{abstract}
Undisciplined and difficulty to find parking space are problems at El Tari Airport Kupang. The purpose of research to determine the capacity and demand of parking space and the effectiveness of parking services. The methods used include analysis of parking characteristics, linear regression, method of Importance Performance Analysis (IPA). The results showed that the demand parking space for car at El Tari Airport in existing condition is already exceeding capacity, while for motorcycle still sufficient. For the next 5 years the demand of parking space is 573 parking spaces (SRP) for cars and 599 SRP for motorcycles. The relationship between parking space demand and the number of passengers are $y=1.463 x-6203.6$ for car and $y=3.3449 x$ - 14565 for motorcycles. For parking service performance with IPA method, there are 7 variables as the main priority improvement, that is the ability of the parking operator to direct the vehicle to the parking lot, arrange the traffic in the parking area, direct the driver in and out of the parking lot, supervision of parking offenders, parking attendant behavior on the driver, circulation arrangement and vehicle parking position expressed by parking signs and markings, and parking patterns in order.
\end{abstract}

Keywords: airport, IPA, parking service, parking space.

\section{PENDAHULUAN}

Bandara El Tari Kupang merupakan bandara tersibuk di Provinsi Nusa Tenggara Timur (NTT) dengan persentase penumpang $58,85 \%$ dari seluruh bandara yang ada di NTT. Dengan pertumbuhan pergerakan penumpang $13,07 \%$ per tahun, sehingga diperlukan pengembangan bandara yang koordinasi antar semua pihak untuk meningkatkan kinerja bandara dan sistem transportasi (Frans, et al., 2014). Salah satunya adalah fasilitas parkir. Pengunjung bandara bukan hanya membutuhkan tempat untuk berjalan, tetapi juga membutuhkan tempat untuk berhenti (Chronika, et al., 2009). Kendaraan pribadi merupakan moda yang paling nyaman dan fleksibel dalam hal waktu tempuh sehingga moda ini menjadi sangat dominan di bandara di seluruh dunia (Budd, et al., 2013). Tarif parkir per jam parkir merupakan strategi manajemen yang umum berdasarkan durasi penggunaan fasilitas parkir (dwell time) (Nourinejad \& Roorda, 2017).
Survei di seluruh dunia menunjukkan bahwa bandara besar biasanya menyediakan antara 200 hingga 1200 ruang parkir per juta total penumpang per tahun di tambah ruang 250 hingga 500 ruang parkir per seribu karyawan (Li, et al., 2008). Kurang tertib parkir dan sulitnya menemukan tempat parkir yang kosong pada saat jam sibuk menjadi masalah yang terjadi di bandara El Tari Kupang. Tentunya hal ini sangat mengganggu pergerakan di sekitar area tersebut. Padahal seharusnya keberadaan suatu kegiatan harus seminimal mungkin menimbulkan gangguan arus lalu lintas di sekitarnya (Sumina, 2010). Melihat permasalahan yang terjadi maka perlu adanya studi lebih lanjut untuk mengkaji kapasitas, kebutuhan, dan kinerja parkir di Bandar Udara El Tari Kupang. Tujuan yang ingin dicapai dalam penelitian ini adalah mengetahui kebutuhan, kapasitas ruang parkir dan efektivitas layanan parkir kendaraan di bandara El Tari Kupang. 


\section{METODE PENELITIAN}

Untuk mendapatkan hasil yang diinginkan, maka perlu sebuah acuan dalam pelaksanaan penelitian yang biasa disebut sebagai metode penelitian.

\subsection{Metode pengumpulan data}

Metode yang digunakan dalam pengumpulan data adalah survei inventarisasi fasilitas parkir survei kendaraan parkir, kuesioner metode IPA, wawancara pengelola parkir, dan studi pustaka.

\subsection{Penentuan jumlah sampel}

Berdasarkan hasil perhitungan dengan rumus Slovin maka survei kuesioner metode IPA untuk pengunjung bandara sebanyak 400 responden.

\subsection{Metode analisis}

1. Analisis Survei Kendaraan Parkir untuk mengetahui kinerja parkir kendaraan

2. Analisis Kebutuhan Ruang Parkir (KRP) untuk mengetahui kebutuhan ruang parkir eksisting dan 5 tahun mendatang.

3. Analisis dengan Metode Importance Performance Analysis (IPA) untuk mengetahui persepsi pengguna parkir terhadap pelayanan parkir kendaraan

\section{KONDISI KINERJA PARKIR}

Ukuran luas efektif untuk meletakkan kendaraan, termasuk ruang bebas dan lebar buka pintu adalah satuan ruang parkir yang biasa disingkat dengan SRP . Jumlah petak parkir mobil yang ada saat ini di Bandara El Tari adalah 238 SRP dan untuk sepeda motor adalah 520 SRP. Dengan analisis karakteristik parkir akan dapat diketahui kinerja parkir dan permasalahan parkir yang terjadi pada daerah studi (Purbanto , 2012). Dalam analisis kondisi kinerja parkir, data parkir yang dianalisis dalam kondisi hari sibuk (peak), yang dilihat berdasarkan jumlah pergerakan penumpang yang paling tinggi.

Data pergerakan penumpang diperoleh dari PT Angkasa Pura I (Persero) Bandara El Tari Kupang. Pada Gambar 1 menunjukkan rata-rata pergerakan penumpang pesawat harian pada bulan Januari paling tinggi terjadi pada hari Selasa dengan rata-rata pergerakan sebanyak 5231,6 penumpang kemudian diikuti dengan hari Rabu, Jumat, Senin, Kamis, Sabtu, dan Minggu dengan rata-rata pergerakan penumpang secara berturut-turut adalah sebanyak 4934 penumpang, 4880,75 penumpang, 4860,8 penumpang, 4810,75 penumpang, 4614 penumpang, dan 4401,8 penumpang.

Berdasarkan rata-rata pergerakan penumpang dan pesawat pada bulan Januari 2017 menunjukkan bahwa hari Senin, Selasa, Rabu, dan Jumat adalah hari di mana pergerakan penumpang paling tinggi, sehingga dilakukan pengambilan data parkir pada hari Senin, 30 Januari 2017, Selasa, 31 Januari 2017, Rabu, 1 Februari 2017 dan Jumat, 3 Februari 2017.

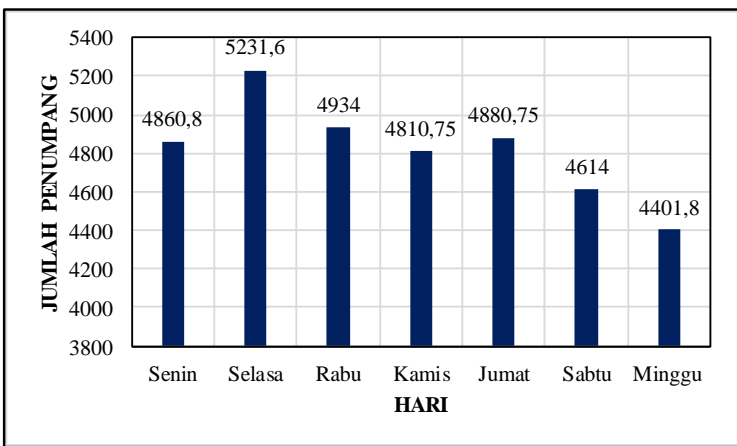

Gambar 1. Rata-rata pergerakan penumpang harian bulan Januari 2017

\subsection{Akumulasi parkir}

Akumulasi parkir merupakan jumlah kendaraan yang parkir dalam rentang satu jam. Pada Gambar 2 menunjukkan akumulasi parkir mobil yang maksimum terjadi pada hari Selasa dengan jumlah kendaraan maksimum yang parkir berada pada rentang pukul 12:00-13:00 sebanyak 281 unit. Sedangkan hari Senin, Rabu dan Jumat akumulasi parkir mobil maksimum terjadi pada rentang pukul 12:00-13:00 secara berturut-turut adalah sebanyak 250, 204, dan 234 unit. Gambar 3 menunjukkan akumulasi parkir sepeda motor yang maksimum terjadi pada hari Selasa dengan jumlah kendaraan maksimum yang parkir berada pada rentang pukul 13:00-14:00 yaitu sebanyak 294 kendaraan. Sedangkan akumulasi maksimum parkir sepeda motor pada hari Senin, Rabu, dan Jumat secara berturut turut adalah 240 kendaraan pukul 14:00-15:00, 122 kendaraan pukul 08:00-09:00, dan 173 kendaraan pukul 12:00-13:00

\subsection{Volume parkir}

Pada Gambar 4 menunjukkan volume parkir mobil paling banyak terjadi pada hari Selasa dengan jumlah mobil yang masuk 
sebanyak 2779 unit, sedangkan jumlah mobil yang masuk pada hari Senin, Rabu dan Jumat secara berturut-turut adalah 2236 unit, 2143 unit, dan 1915 unit, Gambar 5 menunjukkan volume parkir sepeda motor paling banyak terjadi pada hari Selasa dengan jumlah sepeda motor yang masuk sebanyak 2098 unit, sedangkan jumlah sepeda motor yang masuk pada hari Senin, Rabu dan Jumat secara berturut-turut adalah 1631 unit, 843 unit, dan 1198 unit.

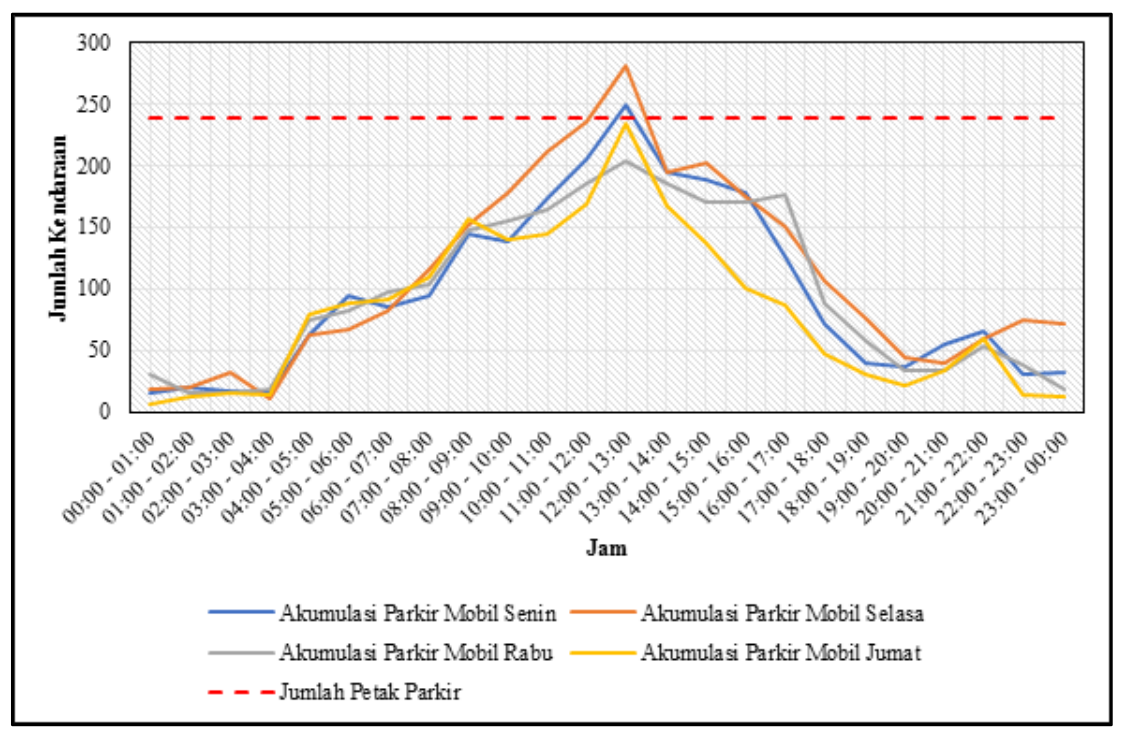

Gambar 2. Akumulasi parkir mobil

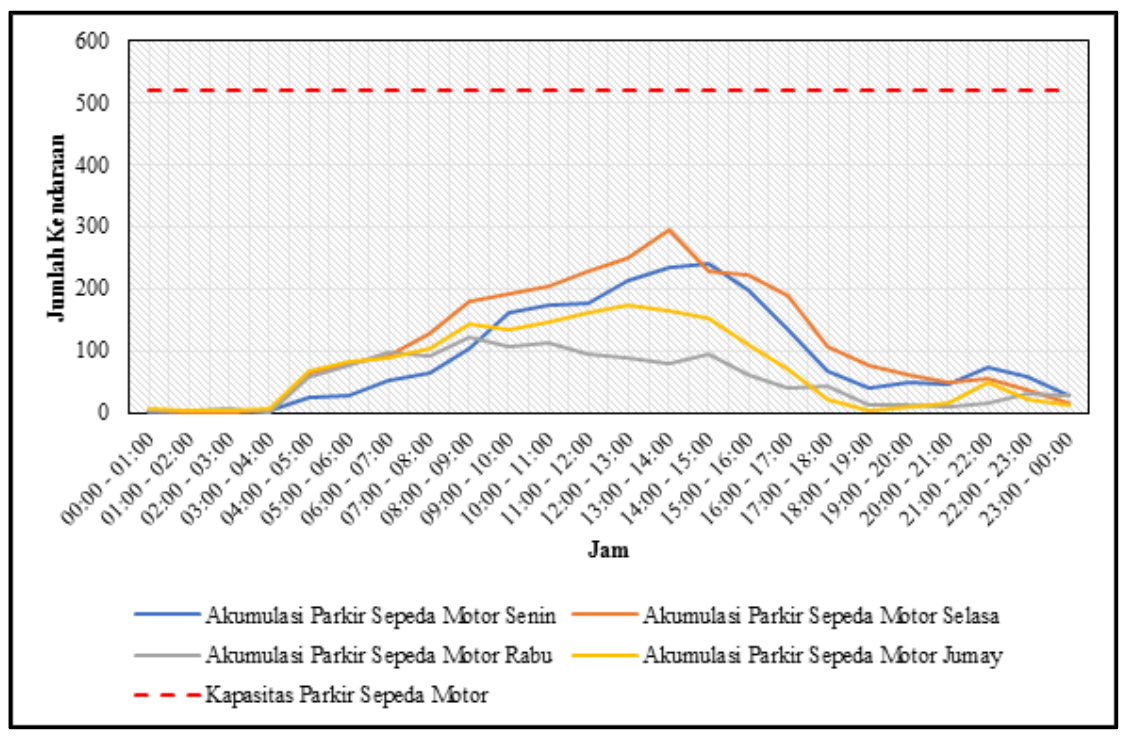

Gambar 3. Akumulasi parkir sepeda motor 


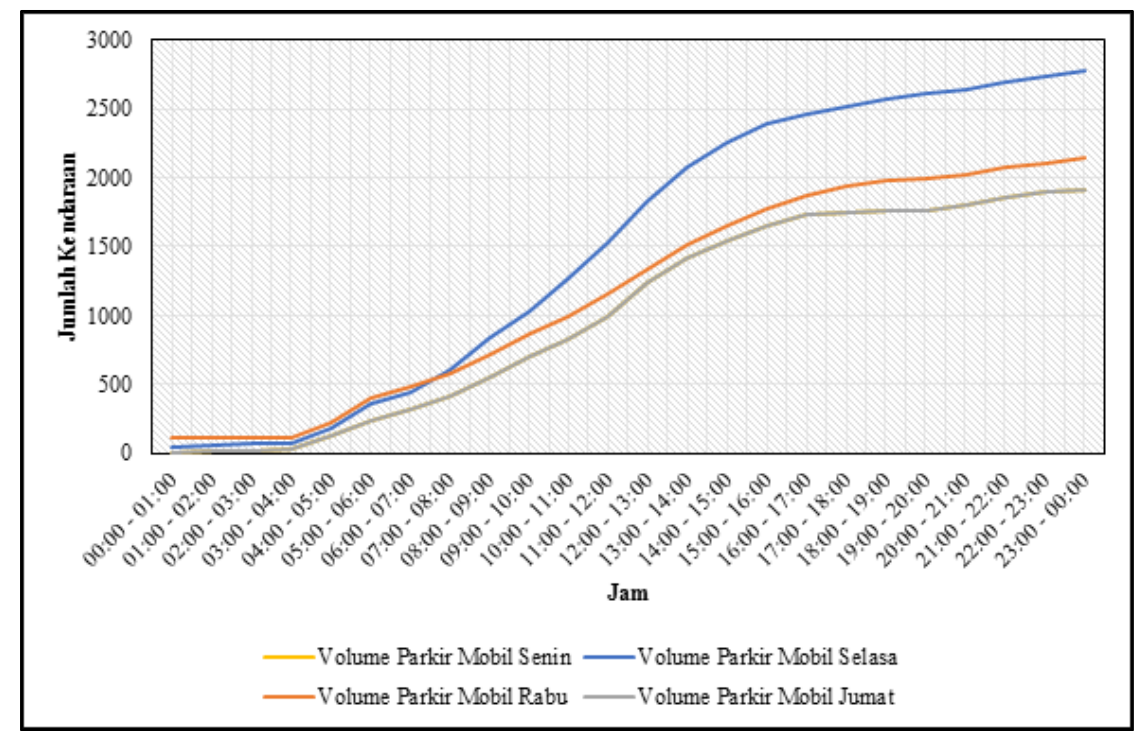

Gambar 4. Volume parkir mobil

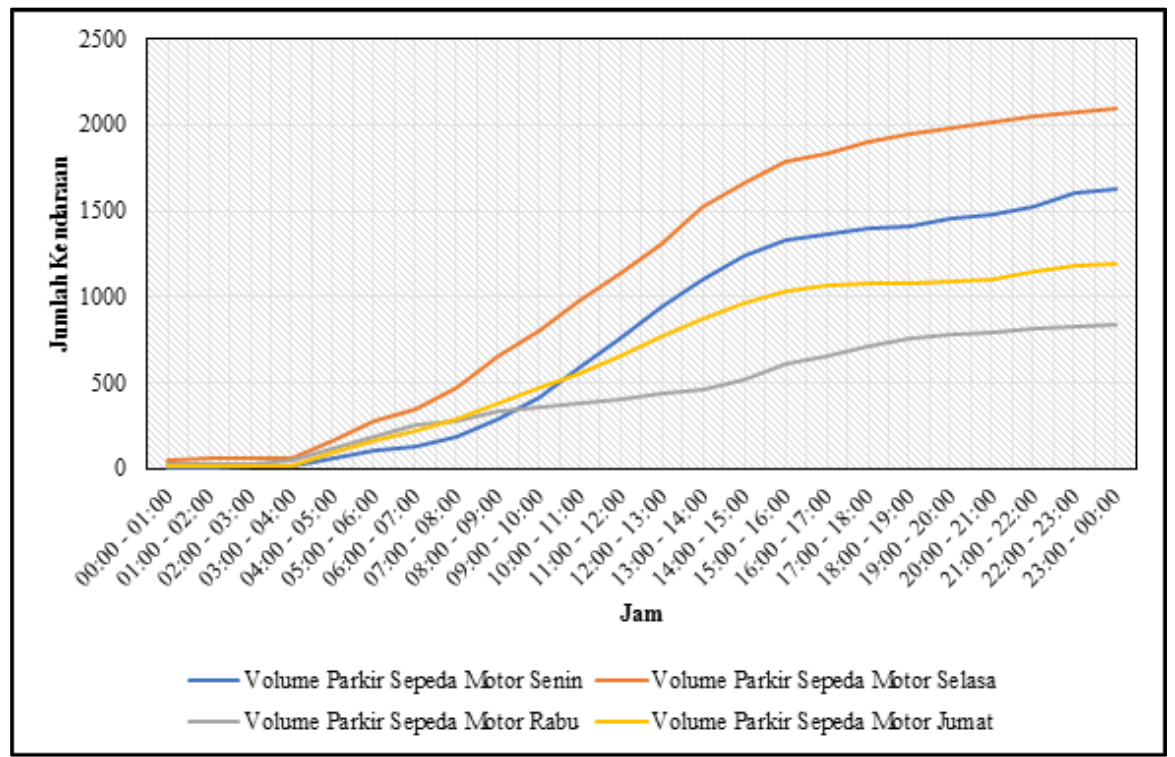

Gambar 5. Volume parkir sepeda motor

\subsection{Durasi parkir}

Durasi parkir merupakan rentang waktu kendaraan diparkir. Pada Gambar 6 menunjukkan durasi parkir rata-rata per hari untuk mobil lebih rendah jika dibandingkan dengan durasi parkir sepeda motor. Tapi secara keseluruhan durasi parkir rata-rata kendaraan yang parkir di Bandar Udara El Tari Kupang masih relatif rendah karena masih di bawah 2 jam yang menggambarkan kendaraan yang parkir memilik mobilitas yang cukup tinggi.

\subsection{Kapasitas parkir}

Kapasitas parkir adalah banyaknya kendaraan yang dapat dilayani oleh lahan parkir selama satu jam pelayanan. Kendaraan pemakai fasilitas parkir ini ditinjau dari prosesnya datang, berdiam diri (parkir) dan pergi meninggalkan fasilitas parkir. Banyaknya kendaraan yang dapat dilayani oleh lahan parkir selama per jam pelayanan pada hari Senin, Selasa, Rabu, dan Jumat secara berturut-turut adalah 240,217 kend/jam, 263,973 kend/jam, $222,788 \mathrm{kend} / \mathrm{jam}$, dan 230,184 kend/jam untuk mobil sedangkan untuk sepeda motor adalah $387,858 \mathrm{kend} / \mathrm{jam}, 395,878 \mathrm{kend} / \mathrm{jam}, 342,324$ $\mathrm{kend} / \mathrm{jam}$ dan 353, $031 \mathrm{kend} / \mathrm{jam}$.

Hubungan antara kapasitas parkir dan jumlah pergerakan penumpang pesawat harian, maka model yang didapatkan dapat dilihat pada Gambar 7 dan Gambar 8. Berdasarkan Gambar 7, diketahui model kapasitas parkir mobil di Bandar Udara El Tari adalah $y=0,698 x$ 
- 2847,9 dengan hasil koefisien determinasi $\left(\mathrm{R}^{2}\right)$ sebesar 0,8756 yang menunjukkan bahwa pengaruh jumlah pergerakan penumpang terhadap kapasitas parkir di Bandar Udara El Tari Kupang adalah sebesar 87,56\%. Berdasarkan Gambar 8, diketahui model kapasitas parkir sepeda di Bandar Udara El Tari adalah $\mathrm{y}=0,9883 \mathrm{x}-4001,3$ dengan hasil koefisien determinasi $\left(\mathrm{R}^{2}\right)$ sebesar 0,8297 yang menunjukkan bahwa pengaruh jumlah pergerakan penumpang terhadap kapasitas parkir di Bandar Udara El Tari Kupang adalah sebesar $82,97 \%$.

\subsection{Pergantian parkir}

Pergantian parkir merupakan tingkat penggunaaan ruang parkir yang diperoleh dari pembagian volume parkir dan jumlah petak parkir yang tersedia dalam rentang waktu harian. Pada Gambar 9 menunjukkan tingkat pergantian parkir (parking turn over) ada empat hari Senin, Selasa, Rabu dan Jumat. Dari grafik tersebut terlihat bahwa tingkat pergantian parkir paling tinggi terjadi pada hari Selasa untuk parkir mobil yaitu dengan 11,676. Artinya pada hari Selasa, satu petak parkir mobil akan ditempati oleh 11,676 unit mobil. Sedangkan untuk sepeda motor tingkat pergantian paling tinggi terjadi pada hari Selasa dengan 4,035, yang artinya pada hari Selasa, satu petak parkir sepeda motor akan ditempati 4,035 unit sepeda motor.

\subsection{Indeks parkir}

Indeks parkir adalah persentase jumlah tempat parkir yang tersedia dengan jumlah kendaraan yang menempati tempat parkir. Pada
Gambar 10 menunjukkan indeks parkir harian mobil pada hari Senin, Selasa, Rabu, dan Jumat dengan interval waktu setiap satu jam. Indeks parkir pada hari Selasa adalah yang tertinggi bila dibandingkan dengan indeks parkir pada hari Senin, Rabu, dan Jumat, yaitu dengan indeks parkir sebesar 118,07\% pada pukul 12:00-13:00. Sedangkan indeks parkir maksimum pada hari Senin, Rabu dan Jumat secara berturut-turut adalah 105,04\%, (pukul 12:00-13:00), 85,71\% (pukul 12:00-13:00), dan 98,32\% (pukul 12:0013:00). Dengan indeks parkir yang melebihi $100 \%$ menggambarkan bahwa seluruh area parkir dipenuhi kendaraan (mobil) bahkan sebagian harus parkir di tempat yang tidak seharusnya digunakan sebagai tempat parkir. Gambar 11 menunjukkan indeks parkir harian sepeda motor pada hari Senin, Selasa, Rabu, dan Jumat dengan interval waktu setiap satu jam. Indeks parkir pada hari Selasa adalah yang tertinggi bila dibandingkan dengan hari lainnya. Pada hari Selasa mulai indeks parkir maksimum sepeda motor yaitu mencapai $56,54 \%$ pada pukul 13:00-14:00. Sedangkan pada hari Senin, Rabu dan Jumat indeks parkir maksimum secara berturut-turut adalah sebesar $46,15 \%$ (pukul 14:00-15:00), 23,46\% (pukul 18:00-09:00) dan 33,27\% (pukul 12:00-13:00) . Indeks parkir sepeda motor yang kecil ini menggambarkan kapasitas parkir untuk sepeda motor masih sangat cukup untuk menampung sepeda motor yang masuk ke Bandar Udara El Tari Kupang. Namun keadaan ini tidak sepenuhnya menggambar-kan keadaan di lapangan karena ada kendaraan yang parkir pada area larangan parkir.

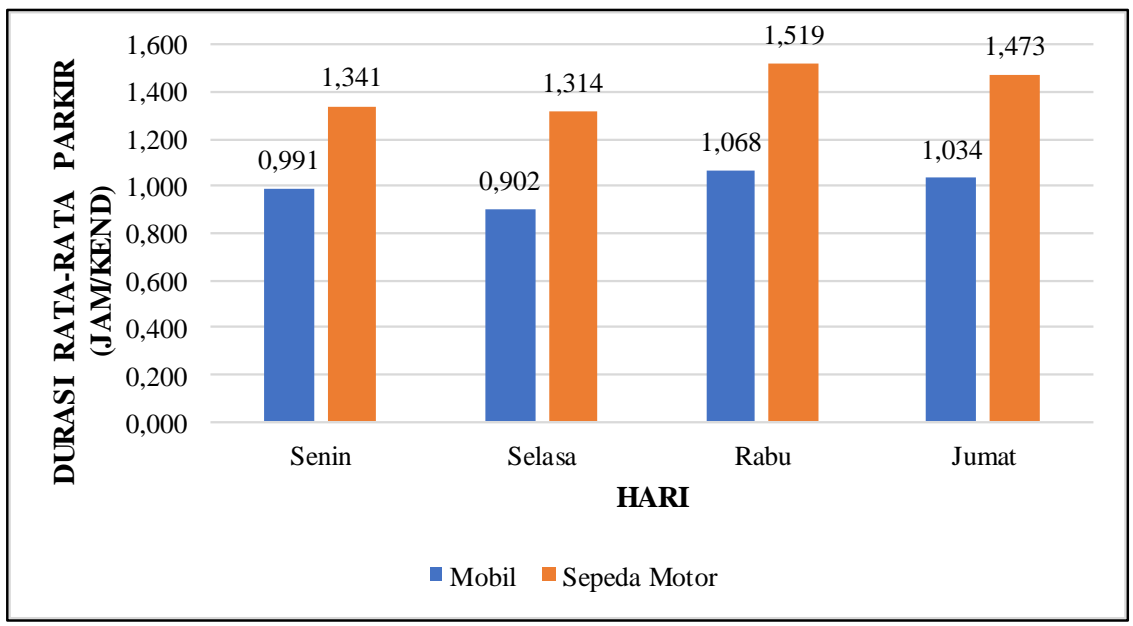

Gambar 6. Durasi parkir kendaraan 


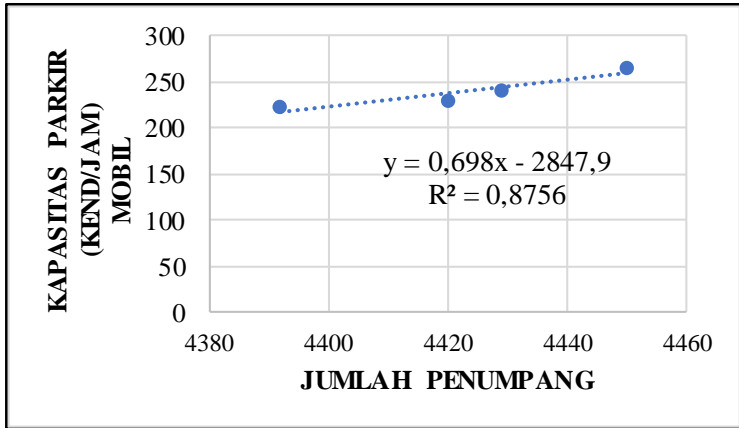

Gambar 7. Hubungan jumlah penumpang dengan kapasitas parkir mobil

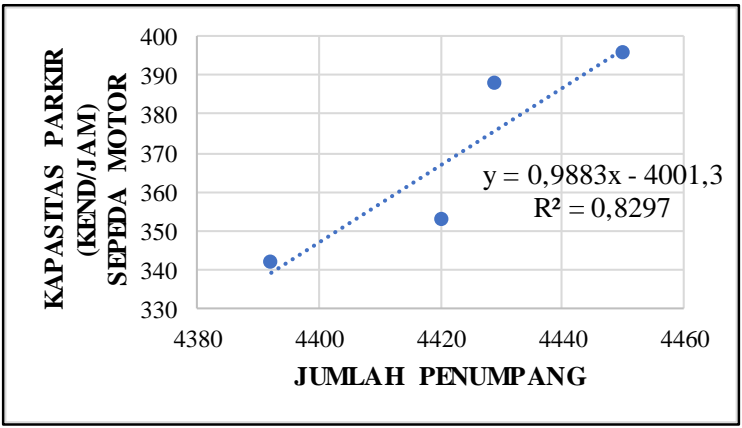

Gambar 8. Hubungan jumlah penumpang dengan kapasitas parkir sepeda motor

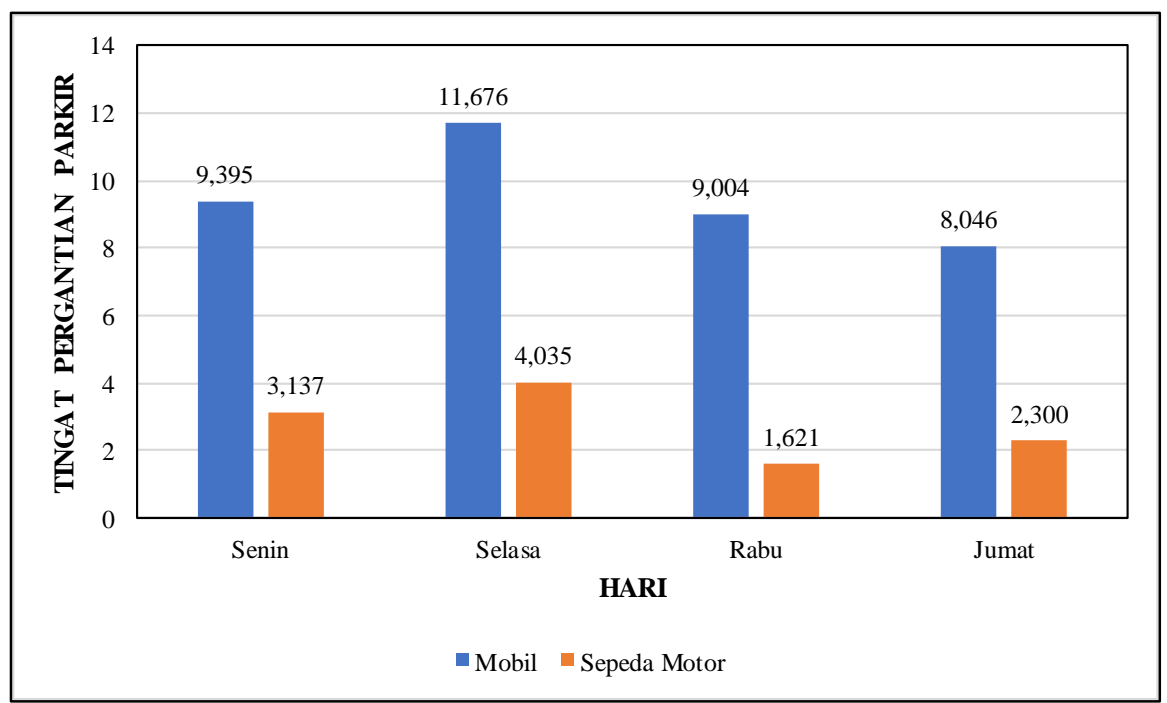

Gambar 9. Tingkat pergantian parkir

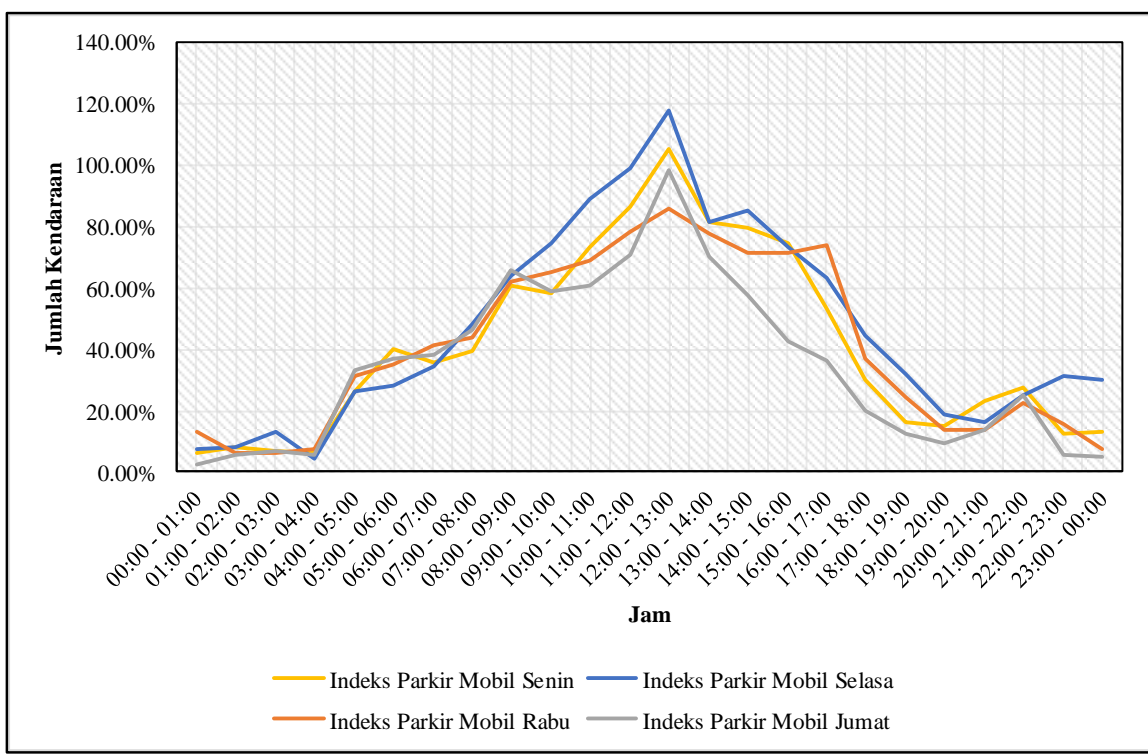

Gambar 10. Indeks parkir mobil 


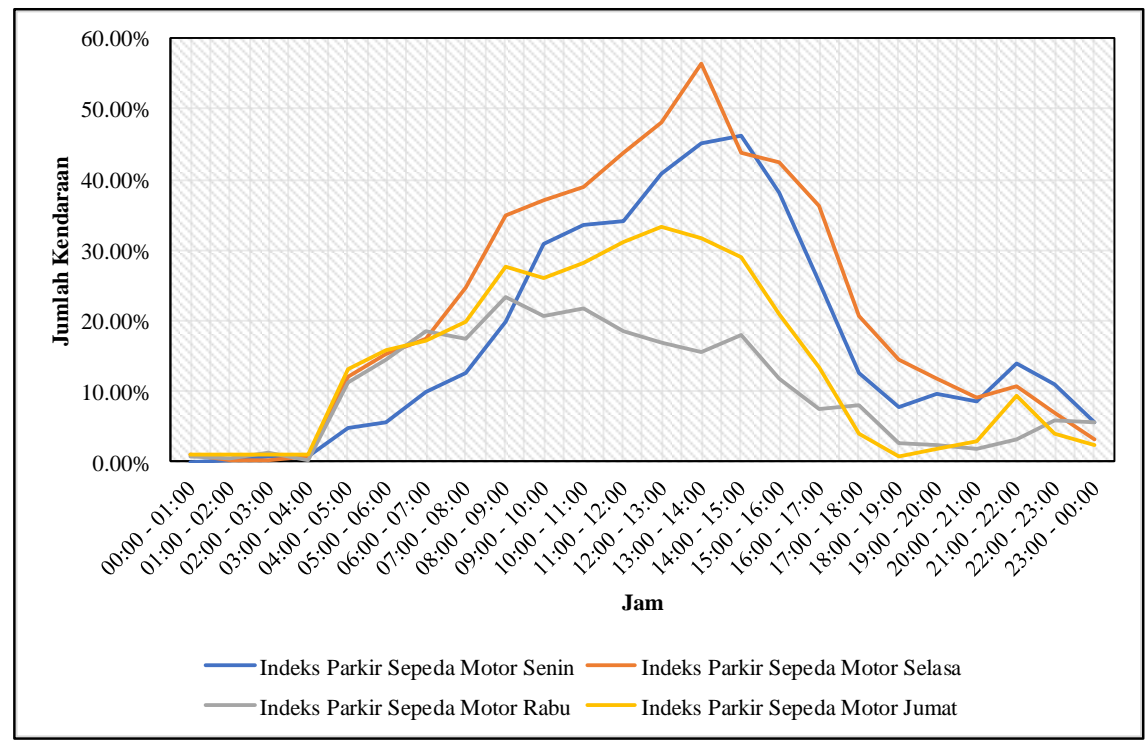

Gambar 11. Indeks parkir sepeda motor

\section{KEBUTUHAN RUANG PARKIR (KRP)}

Perhitungan kebutuhan ruang parkir (KRP) menggunakan perumusan Dirjen Perhubungan Darat.

$\mathrm{KRP}=\mathrm{F} 1 \times \mathrm{F} 2 \times \mathrm{VPH}$

dengan

KRP : Kebutuhan ruang parkir (SRP)

F1 : Faktor akumulasi parkir

F2 : Faktor fluktuasi $(1,10)$

VPH : Volume parkir harian

Hasil perhitungan kebutuhan ruang parkir eksisting untuk hari Senin, Selasa, Rabu, dan Jumat secara berturut-turut adalah 275 SRP, 310 SRP, 225 SRP, dan 258 SRP, sedangkan KRP sepeda motor pada hari Senin, Selasa, Rabu, dan Jumat secara berturut-turut adalah 264 SRP, 324 SRP, 135 SRP, dan 191 SRP dengan model yang merupakan hubungan antara KRP dan jumlah pergerakan penumpang yang ditunjukkan ada Gambar 12 dan Gambar 13 yaitu $y=1,463 x$ - 6203,6 dengan determinasi $\left(R^{2}\right)$ 0,9881 untuk mobil dan $\mathrm{y}=3,3449 \mathrm{x}-14565$ dengan koefisien determinasi $\left(\mathrm{R}^{2}\right)$ 0,9454 untuk sepeda motor. Hal ini menunjukkan bahwa mayoritas pengguna parkir mobil dan sepeda motor ke Bandar Udara El Tari hanya untuk mengantar maupun menjemput penumpang. Maka dengan memproyeksi pertumbuhan penumpang 13,07\% yang ditunjukkan pada Tabel 1, maka didapatkan KRP pada tahun 2022 adalah 573 SRP untuk mobil dan 599 SRP untuk sepeda motor

Direncanakan dimensi kendaraan menurut (Direktorat Jendral Perhubungan Darat,
1998) dengan $0,75 \times 2$ meter untuk sepeda motor dan 2,5 x 5 meter untuk mobil, serta menggunakan lebar gang 1,6 meter untuk sepeda motor dan 8 meter untuk mobil. Selain itu, dilakukan perhitungan luas lahan menggunakan pola parkir $90^{\circ}$ untuk menghemat kebutuhan lahan yang ada. Dari hasil perhitungan didapatkan luas lahan yang dibutuhkan adalah 17373,12 $\mathrm{m}^{2}$ tanpa memperhitungkan panjang jalur sirkulasi. Sehubungan dengan kebijakan baru dari PT. Angkasa Pura I (Persero) dan PRIMKOPAU El Tari bahwa akan dilakukan penataan dan perluasan area parkir Bandara El Tari Kupang, maka perencanaan kebutuhan lahan parkir dilakukan berdasarkan ketersediaan lahan yang ada. Luas lahan parkir eksisting adalah $9240 \mathrm{~m}^{2}$. Dengan luas lahan kosong $72.910 \mathrm{~m}^{2}$, makaseperti yang ditunjukkan pada Gambar 14, perencanaan kawasan parkir yang baru adalah

- Untuk kawasan parkir mobil T1 memiliki luas $7770 \mathrm{~m}^{2}$ dengan perencanaan alternatifnya adalah taman parkir.

- Untuk kawasan parkir sepeda motor memiliki luas $3175 \mathrm{~m}^{2}$ dengan perencanaan alternatifnya adalah taman parkir.

- Untuk kawasan parkir bus/truck memiliki luas $5614 \mathrm{~m}^{2}$ dengan perencanaan alternatifnya adalah taman parkir 


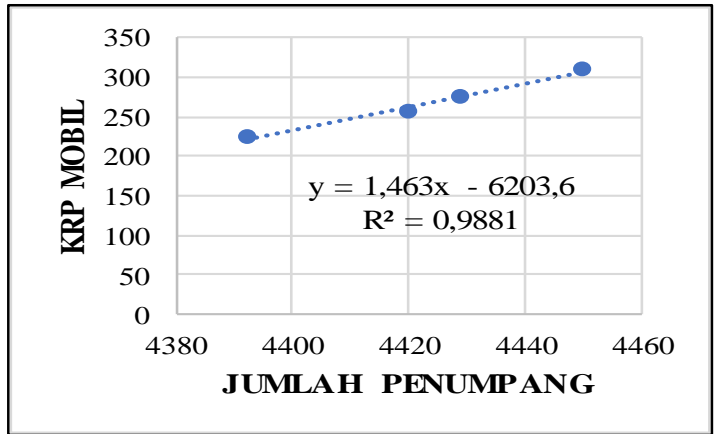

Gambar 12. Hubungan jumlah penumpang dengan KRP mobil

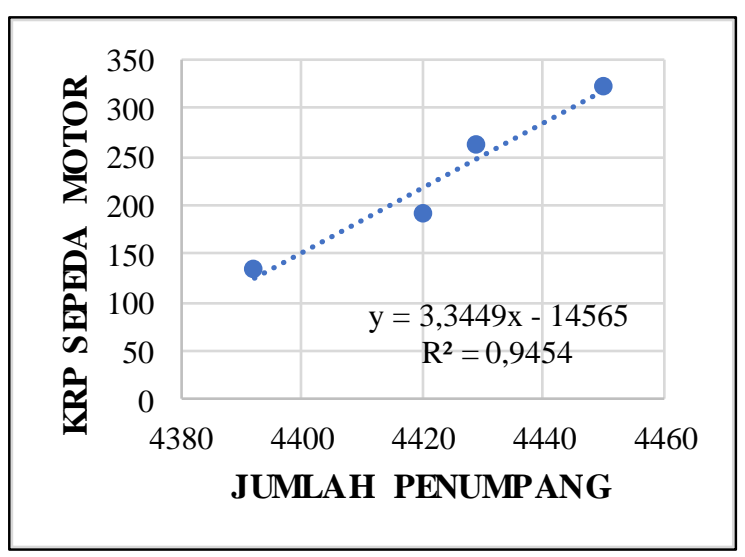

Gambar 13. Hubungan jumlah penumpang dengan KRP sepeda motor

Tabel 1. Prediksi KRP 5 tahun mendatang

\begin{tabular}{|c|c|c|c|}
\hline \multirow{2}{*}{ Tahun } & \multirow{2}{*}{$\begin{array}{c}\text { Penumpang } \\
\text { (Jiwa) }\end{array}$} & \multicolumn{2}{|c|}{ KRP } \\
\cline { 3 - 4 } & $\begin{array}{c}\text { Mobil } \\
\text { (SRP) }\end{array}$ & $\begin{array}{c}\text { Sepeda } \\
\text { Motor } \\
\text { (SRP) }\end{array}$ \\
\hline 2017 & 4450 & 310 & 324 \\
\hline 2018 & 5031,67 & 351 & 366 \\
\hline 2019 & 5689,36 & 396 & 414 \\
\hline 2020 & 6433,03 & 448 & 468 \\
\hline 2021 & 7273,90 & 507 & 530 \\
\hline 2022 & 8224,68 & 573 & 599 \\
\hline
\end{tabular}

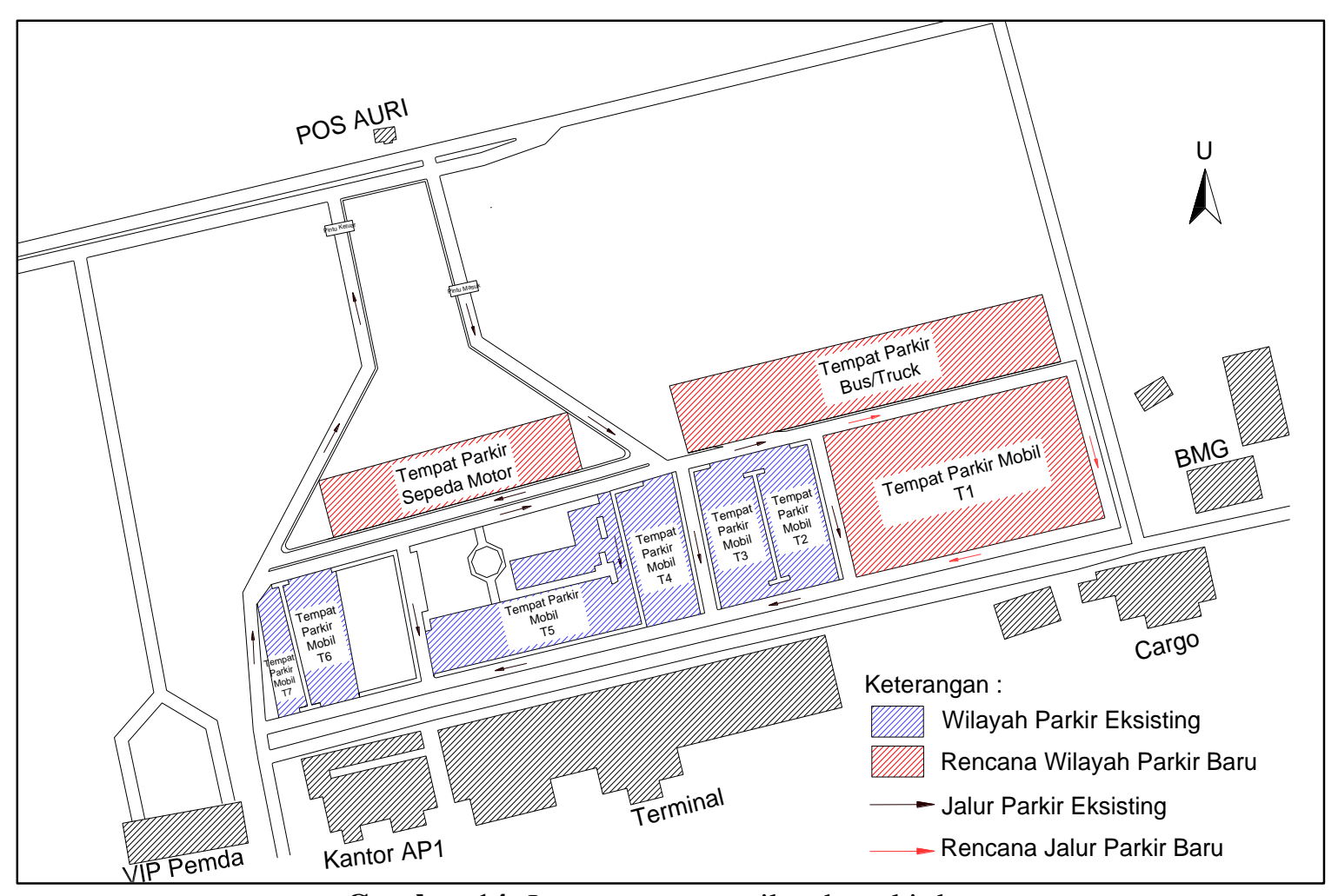

Gambar 14. Layout rencana wilayah parkir baru 


\section{IMPORTANCE ANALYSIS (IPA)}

Hasil Importance Performance Analysis (IPA) untuk kinerja pelayanan parkir :

- Kuadran I (Prioritas Utama) dengan tingkat kepentingan yang tinggi tapi tingkat kinerjanya rendah, berisi 7 item yaitu kemampuan petugas parkir mengarahkan tata cara memarkirkan kendaraan (x19), kemampuan petugas parkir mengatur lalu lintas di kawasan parkir (x18), kemampuan petugas parkir memandu pengemudi masuk dan keluar tempat parkir (x17), pengawasan parkir terhadap pelanggaran parkir (x15), pelataran parkir diatur sirkulasi dan posisi parkir kendaraan yang dinyatakan dengan rambu lalu lintas atau marka jalan (x6), perilaku petugas parkir dalam menghadapi pemarkir (x20), pola parkir yang teratur (x13).

- Kuadran II (Pertahankan Prestasi) dengan tingkat kepentingan yang tinggi dan tingkat kinerjanya tinggi, berisi 8 item, yaitu keamanan kendaraan berserta perlengkapan yang diparkir (x16), kebersihan pelataran parkir (x8), pintu elektronik (x25), Pos petugas (x21), pembatasan lokasi parkir dengan larangan parkir (x2), pintu keluar dan masuk (x23), lampu penerangan (x22), penetapan sistem karcis (x4)

- Kuadran III (Prioritas Rendah) dengan tingkat kepentingan yang rendah dan tingkat kinerjanya rendah, berisi 4 item yang terdiri dari jalur sirkulasi, gang, dan modul yang lancar (x14), kondisi perkerasan parkir (x9), kapasitas parkir sesuai standar (x10), kemudahan dijangkau oleh pengguna jasa (x5).

- Kuadran IV (Berlebihan) dengan tingkat kepentingan yang rendah tapi tingkat kinerjanya tinggi, berisi 6 item yang terdiri dari penetapan tarif progresif sesuai dengan durasi parkir (x3), kemudahan bagi pengguna jasa untuk menemukan kendaraannya (x7), penetapan tarif dasar parkir yang optimal (x1), luas lahan parkir sesuai standar (x11), ruang bebas kendaraan yang cukup (x12), alat pencatat waktu elektronik (x24).

\section{KESIMPULAN}

1. Karakteristik layanan parkir

a. Akumulasi parkir maksimum mobil terjadi pada hari Selasa yang ada pada rentang pukul 12.00-13.00 yaitu sebanyak 281 unit, sedangkan akumulasi parkir maksimum sepeda motor terjadi pada hari Selasa dengan jumlah kendaraan maksimum yang parkir berada pada rentang pukul 13.00-14.00 yaitu sebanyak 294 kendaraan

b. Volume parkir mobil paling banyak terjadi pada hari Selasa dengan jumlah mobil yang menggunakan fasilitas parkir sebanyak 2779 unit sedangkan volume parkir sepeda motor paling banyak terjadi pada hari Selasa dengan jumlah sepeda motor yang menggunakan fasilitas parkir sebanyak 2098 unit.

c. Rata-rata durasi parkir untuk mobil paling lama terjadi pada hari Rabu yaitu 1,068 jam/kendaraan sedangkan untuk sepeda motor yaitu $1,519 \mathrm{jam} /$ kendaraan.

d. Model kapasitas parkir untuk mobil adalah $y=0,698 x-2847,9$ sedangkan untuk sepeda motor adalah $\mathrm{y}=0,9883 \mathrm{x}-$ 4001,3

e. Tingkat pergantian parkir paling tinggi terjadi pada hari Selasa untuk parkir mobil yaitu dengan 11,676, sedangkan untuk sepeda motor tingkat pergantian paling tinggi terjadi pada hari Selasa dengan 4,035

f. Indeks parkir tertinggi terjadi pada hari Selasa yaitu dengan indeks parkir sebesar 118,07\% pada pukul 12:00-13:00 untuk mobil, dan 56,54\% pada pukul 13:0014:00 untuk sepeda motor

2. Tingkat kinerja layanan parkir

a. Atribut pelayanan parkir yang harus mendapatkan perhatian utama dalam hal perbaikan dari pihak pengelola adalah kemampuan petugas parkir mengarahkan tata acara memarkirkan kendaraan (x19), kemampuan petugas parkir mengatur lalu lintas di kawasan parkir (x18), kemampuan petugas parkir memandu pengemudi masuk dan keluar tempat parkir (x17), pengawasan parkir terhadap pelanggaran parkir (x15), perilaku petugas parkir dalam menghadapi pemarkir (x20), pelataran parkir diatur sirkulasi dan posisi parkir kendaraan yang dinyatakan dengan rambu lalu lintas atau 
marka jalan $(x \neg 6)$, dan pola parkir yang teratur (x13).

3. Kebutuhan lahan parkir

a. Pada kondisi eksisting, kebutuhan ruang parkir (KRP) untuk mobil adalah 310 SRP, sedangkan KRP sepeda motor adalah 324 SRP.

b. Pada kondisi 5 tahun mendatang, kebutuhan ruang parkir (KRP) pada tahun 2022 adalah 573 SRP untuk mobil dan 599 SRP untuk sepeda motor.

\section{DAFTAR PUSTAKA}

[1] Budd, L., Ison, S. \& Budd, T., 2013. An Empirical Examination Of The Growing Phenomenon Of Off-Site Residential Car Parking Provision: The Situation At Uk Airports. Transportation Research Part A: Policy and Practice, p. 26-34.

[2] Chronika, L., Mangunsong, L. \& Narsih, 2009. Analisis kepuasan Konsumen terhadap Kualitas Pelayanan Parkir di Mega Mall A. Yani Pontianak. Jurnal Aplikasi Manajemen, pp. 1018-1026.
[3] Direktorat Jendral Perhubungan Darat, 1998. Pedoman Perencanaan dan Pengoperasian Fasilitas Parkir. Jakarta: Direktorat Jendral Perhubungan Darat.

[4] Frans, J. H., Sulistio, H. \& Wicaksono, A., 2014. Kajian Kapasitas, Pelayanan dan Strategi Pengembangan Bandar Udara El Tari Kupang. Jurnal Pembangunan dan Alam Lestari, pp. 44-53.

[5] Li, J., Tay, R. \& de Barros, A., 2008. Quantitative Analysis of Automobile Parking at Airports, Calgari: University of Calgary.

[6] Nourinejad, M. \& Roorda, . M. J., 2017. Impact of hourly parking pricing on travel demand. Transportation Research Part A, pp. 28-45.

[7] Purbanto , I. G. R., 2012. Karakteristik Parkir Pinggir Jalan (On Street Parking) Dan Pengaruhnya Terhadap Kinerja Ruas Jalan (Studi Kasus : Pada Ruas Jalan Sutoyu Denpasar). Jurnal Ilmiah Teknik Sipil, pp. 167-176.

[8] Sumina, S., 2010. Analisis Kapasitas Dan Karakteristik Parkir Kendaraan Di Lokasi Perbelanjaan (Studi Kasus Surakarta Grand Mall Surakarta). Jurnal Teknik Sipil dan Arsitektur, pp. 76-87. 